\title{
Industrial challenges with photovoltaic applications: a systematic review
}

\section{Desafios industriais com aplicações fotovoltaicas: uma revisão sistemática}

\author{
Antonio Carlos Franco Mestrando em Engenharia de Produção. Universidade Tecnológica Federal do Paraná (UTFPR) - \\ Brasil.francoancf@hotmail.com \\ Cassiano Moro Piekarski Doutor em Engenharia de Produção. Universidade Tecnológica Federal do Paraná (UTFPR) - \\ Brasil. piekarski@utfpr.edu.br \\ Luciane Silva Franco Mestranda em Engenharia de Produção. Universidade Tecnológica Federal do Paraná (UTFPR) - \\ Brasil. lu05-franco@hotmail.com
}

\begin{abstract}
The industrial energy matrix in several countries is formed by several primary sources, such as fossil fuels. However, the advancement of technologies, equipment and industrial machinery results in growing demand for environmental and energy impacts, resulting in the demand for clean energy sources. This study aims to analyze applications and the environmental, economic and social impacts of photovoltaic solar energy in the industrial sector. The methodology used was based on the application of Methodi Ordinatio, with the databases Science Direct, Scopus and Web of Science, resulting in the complete analysis of 21 articles without time frame. Among the results, we highlight the applications of clean energy in water heating for industrial restaurants and bathrooms, in the generation of electricity for equipment, and as a vehicle fuel in the internal fleet, as well as for the substitution of

natural gas. From the analyzed articles, the following results were obtained: $19.7 \%$ found technical benefits for the use of clean sources of photovoltaic energy in industry; $12.8 \%$ affirm that human and economic development requires the availability of energy resources for the production of renewable electric energy close to the end customer, minimizing losses in distribution lines; and $67.5 \%$ the diversification of the industrial energy matrix, which demonstrates several economic, environmental and social advantages, thus reducing the dependence on fossil resources. The use of green energy sources favors the industrial sector, resulting in increased production, reduced costs and a sustainable and competitive performance.
\end{abstract}

Keywords: Sustainability. Renewable Energy. Photovoltaic Energy. Cost. Industry.

\section{RESUMO}

A matriz energética industrial em vários países é formada por várias fontes primárias, como combustíveis fósseis. No entanto, o avanço de tecnologias, equipamentos e máquinas industriais resulta em uma demanda crescente por impactos ambientais e energéticos, resultando na demanda por fontes de energia limpa. Este estudo tem como objetivo analisar aplicações e os impactos ambientais, econômicos e sociais da energia solar fotovoltaica no setor industrial. A metodologia utilizada foi baseada na aplicação do Methodi Ordinatio, com as bases de dados Science Direct, Scopus e Web of Science, resultando na análise completa de 21 artigos sem recorte temporal. Entre os resultados, destacamos as aplicações de energia limpa no aquecimento de água de restaurantes, banheiros industriais, geração de eletricidade para equipamentos, como combustível veicular para a frota interna e substituição ao gás natural. Dos artigos analisados, foram obtidos os seguintes resultados: $19,7 \%$ encontraram benefícios técnicos para o uso de fontes limpas de energia fotovoltaica na indústria; $12,8 \%$ afirmam que o desenvolvimento humano e econômico requer a disponibilidade de recursos energéticos para a produção de energia elétrica renovável junto ao consumidor final, minimizando as perdas nas linhas de distribuição; e 67,5\% a diversificação da matriz energética industrial, que demonstra diversas vantagens econômicas, ambientais e sociais, reduzindo a dependência de recursos fósseis. $\mathrm{O}$ uso de fontes de energia verde favorece o setor industrial, resultando em aumento da produção, redução de custos, desempenho sustentável e competitivo.

Palavras-chave: Sustentabilidade. Energia renovável. Energia fotovoltaica. Custo. Indústria. 


\section{INTRODUCTION}

In this century, energy has become an indispensable source in several countries, contributing to the growth of technology, economics and population, and meeting the high demand for energy in the world (SAHAYM; NORTON, 2008). Countries with abundant natural resources make it possible to efficiently minimize the use of fossil sources and the emission of polluting gases into the atmosphere. The process of implementing energy strategies reduces dependence on the use of polluting energy sources (DISPENZA et al., 2019).

The development of the industrial economy, through the use of energy that uses natural sources, contributes to the increase in the degradation of the environment. The use of traditional energy resources impacts the growth of $\mathrm{CO} 2$ in the atmosphere, resulting in the impact of the environmental quality (KARACA; TASDEMIR, 2013). The degradation of the environment is encouraged by the high number of greenhouse gas emissions, such as methane, CO2 and nitrogen oxide (FAMIGLIETTI et al., 2020).

The great negative impacts on the environment and the international value with the reduction of oil in the market have boosted oil plants in minimizing greenhouse gas (GHG) emissions, without impacting the economic investments of the industries (MÜLLER et al., 2017). Approximately 65\% of CO2 emissions are activities related to industrial systems (SHEIKH et al., 2018).

Research on industrial energy quality is fundamental to understanding the supply chain in the generation and transmission of electricity. A difficulty identified in the distribution plants is the high prices and the constant change of quality in distribution networks for the supply of energy (GASIA; MIRÓ; CABEZA, 2017). The industrial production process is impacted by constant energy interruptions, influencing its final productive results (KARACA;TASDEMIR, 2013; MANSOOR et al., 2015). Several researchers claim that industrial equipment shows an improvement in energy and environmental efficiency with the use of clean energy sources. Therefore, investment in alternative and renewable technologies generates positive results in the economy and the environment (FAMIGLIETTI et al., 2020; YENIYIL; BOGA; ESME, 2019; DISPENZA et al., 2017; FAN et al., 2017; PATRUSHEVA et al. 2017; PIELICHOWSKA; PIELICHOWSKI, 2014; SAHAYM; NORTON, 2008).

The deployment of clean energy sources in the industry is growing worldwide such as: the generation of solar, geothermal, wind energy and the use of biomass to replace energies that use fossil fuels, which points to their positive economic and environmental characteristics (SUKUMARAN et al 2020; BUCHER et al. 2019; YENIYIL; BOGA; ESME, 2019; KASTI, 2017; MÜLLER et al., 2017; SHEIK ISMAIL; VELRAJ; RANGANAYAKULU, 2010).

Several studies show the positive relationship of photovoltaic solar energy in the industry, the evolution of the economy and $\mathrm{CO} 2$ emissions as the main responsible for the industrial sector and damage to the environment (DISPENZA et al., 2019; SHEIKH et al., 2018; ISHIMINE et al. , 2011; FINLEY, 1999).

Therefore, studies for the development of photovoltaic solar energy efficient technologies, in the optimization of these emissions, are fundamental for the preservation of the environment and reduction of energy dependence on fossil fuels. The minimization of emissions caused by $\mathrm{CO} 2$ includes: the use of technologies for the generation of photovoltaic solar energy and a satisfactory industrial energy performance to produce clean energies (JRADI; RIFFAT, 2014).

Industrial production systems are fundamental for the proper progress of industries, thus, the consumption of energy from fossil fuels ends up being high, demanding research in order to optimize consumption and use sources of photovoltaic solar energy (FAMIGLIETTI et al., 2020). Solar energy favors the achievement of stability in energy demand in industries (SUKUMARAN et al., 2020).

This type of renewable energy can be captured and used as heat in industrial thermo-solar applications and modified into electrical energy by means of the photovoltaic cells. Solar energy can account for 10 to $17 \%$ of the world's electrical energy in 2045, depending on aspects such as technological advances, energy policy, manufacturing costs and market demand (SUKUMARAN et al 2020). The increasing environmental concerns regarding global warming caused by the likely rise of fuel prices and greenhouse gases emissions are all elements that suggest a further expansion in the use of photovoltaic solar energy sources in the coming years (SOUZA JUNIOR et al., 2019).

Solar energy is an opportunity to generate clean, free and infinite energy. The potential of the generation system is attractive and requires little space for its installation (SOUZA JUNIOR et al., 2019). 
Recently, with technological industrial development, population growth, the diversification of the electrical matrix has become very important in the industrial sector (FAMIGLIETTI et al., 2020). Due to concerns about the environment, the use of photovoltaic systems in industry has become a clean power generation option. These systems enable easy integration into Industrial sectors (SHEIKH et al., 2018).

This research sought to expand the literature on the environmental, economic and social impacts of photovoltaic solar energy, as well as its application in the industrial sector. It is believed that this research can be a contribution to the literature, since no studies were found that related these topics in the industrial sector.

\section{RENEWABLE ENERGY}

Green energies influence economic, social and environmental aspects for the sustainable energy systems of the future. The process for the transition to clean energy sources is essential to minimize impacts in several sectors such as resource preservation, environment, difficulties with the extraction and use of fossil energies and production of electric energy (DISPENZA et al., 2017).

In 2017, the current electricity supply process seeks to reduce the use of fossil energy such as nuclear and coal by $59 \%$, in addition to encouraging the use of renewable energy by 2030 . The increase in the use of renewable energy contributes to the diversification of the energy matrix of countries, and through the encouragement of public policies this participation should increase until 2040 (YENIYIL; BOGA; ESME, 2019).

The process for the implantation of renewable energies in industries is an important transformation involving studies in partnership between universities, companies and the public policy system (SHEIK ISMAIL; VELRAJ; RANGANAYAKULU, 2010).

In developed countries, energy distribution and generation systems have grown rapidly through research on global energy capacity (JRADI; RIFFAT, 2014). In 1970, the studies analyzed only the economic reduction, in 1980 the reliability systems of machines and equipment (PIELICHOWSKA;PIELICHOWSKI, 2014).

The implementation of an energy policy seeks to reduce not only coal-based plants, but nuclear plants due to safety issues with the population. This policy links the world movements for an energy transition towards increasing the consumption of renewable energies (KARACA; TASDEMIR, 2013).

Researchers claim that the adoption of clean energy sources on a large scale such as geothermal, solar and wind enables a balance in the supply and demand of energy distribution and generation systems (FAMIGLIETTI et al., 2020; YENIYIL; BOGA; ESME, 2019; FINLEY, 1999). Therefore, a change to clean energy sources requires a change in the energy generation and distribution systems in order to add flexibility and reliability (SAHAYM; Norton, 2008).

Among the diverse possibilities of clean energy sources, photovoltaic energy is a renewable energy option with attractive, promising characteristics and with the potential to meet the energy demands of industrial systems worldwide (YENIYIL; BOGA; ESME, 2019).

\subsection{Photovoltaic Energy}

The global demand for energy is accelerating, fueled by technological advances and global population growth. Therefore, the use of clean energy sources is essential due to the reliable and infinite economic aspects to meet the demands for energy in the future (PIELICHOWSKA; PIELICHOWSKI, 2014). Among renewable energies, solar is a free and promising energy opportunity for long-term management with the energy crisis (JRADI; RIFFAT, 2014).

Solar energy is a clean energy opportunity for the future due to the reduction of fossil fuels, impacts on the environment and unlimited reserves. The use of solar energy for the generation of electric energy shows a possibility of success for the global crisis of the energy supply (DISPENZA et al., 2017).

The growth in the generation of photovoltaic panels worldwide occurs in parallel with the development and production of technologies for solar systems. This results in a positive impact for the energy sector and in the minimization of generation costs, favoring the evolution of this clean source in a sustainable way (KASTI, 2017). 
The technological transition process for photovoltaic energy includes social and economic aspects, investigating the influence of the social context for the development of countries, such as the United States and Italy that use photovoltaic energy as a source of supply (SAHAYM; NORTON, 2008).

The production of electricity from solar sources favors a sustainable green transition. Increasingly sophisticated technologies and lower prices contribute to the spread of photovoltaic solar energy generation systems (FINLEY, 1999).

The use of renewable energies in the long term, such as the impacts of photovoltaic energy on energy efficiency and the understanding of climate change can influence the production of clean energy sources (YENIYIL; BOGA; ESME, 2019).

The commercialization of photovoltaic cells varies by country, but its global growth results in an increase in energy consumption, thus showing positive effects on issues such as: global warming, air pollution and climate change. To achieve these results, clean energy solutions need to be studied, generated and implemented properly. Photovoltaic generation systems are positive opportunities in relation to fossil fuels, encouraged by the use of sunlight, an unlimited resource (SAHAYM; NORTON, 2008).

The biggest developments in the performance of photovoltaic systems in the energy conversion process are between $14 \%$ and $31 \%$ of the total incident energy. The dissemination of photovoltaic sources depends on economic aspects to characterize attractive possibilities for investors and investments for longterm technical qualification (SHEIKH et al., 2018). The photovoltaic generation system uses microgenerators, specifically in rural and residential cooperatives (PIELICHOWSKA; PIELICHOWSKI, 2014).

The production of photovoltaic cells in third generation with the use of several new technically cheaper materials, are economically attractive due to the high efficiency and flexibility of the materials. This renewable energy shows a diversity of commercial applications, such as refrigeration and lighting (SAHAYM; Norton, 2008).

Countries with marine abundance can install floating solar power plants for photovoltaic generation and distribution systems, meeting the potential of local and coastal demand (PIELICHOWSKA; PIELICHOWSKI, 2014).

The dissemination of photovoltaic technology and industrial investments makes it possible to break barriers such as the economic instability of energy systems (MÜLLER et al., 2017). The increase in the photovoltaic energy production chain in the industry shows satisfactory results through employment, education and economic indicators (FAN et al., 2017).

The opportunities through clean energy sources are interesting for the implantation in the generation and distribution systems in the industry with interesting results in the sustainable transition (FAMIGLIETTI et al., 2020). Photovoltaic energy enables the evolution of the pillars of the triple bottom line: social, economic and environmental through photovoltaic cells as an essential role in the performance of the energy system (ISENMANN; BEY; WELTER, 2007).

The process of capturing sunlight in electrical energy conversion systems shows satisfactory results to meet the high demands of industrial systems (KARACA; TASDEMIR, 2013).

\section{METHODOLOGY}

A systematic literature review was performed based on the methodology described by Pagani, Kovaleski and Resende (2015), the Methodi Ordinatio, which develops a methodological ordering of relevant high impact articles on' the given theme.

This methodology is based on eleven steps: 1) identification of a new topic for study; 2) determination of the research objective; 3) preliminary search with keywords in the databases; 4) definition of the combination of keywords and databases to be used; 5) final search in databases; 6) filtering procedures; 7) identification of the impact factor, year of publication and number of citations; 8 ) classification of articles using InOrdinatio; 9) location of articles in full format; 10) reading and systematic analysis of articles; 11) answer to the study objective. 
The investigation steps were carried out according to the databases used and the results obtained (FIGURE 1).

Figure 1 - Co-occurrence of terms - final portfolio

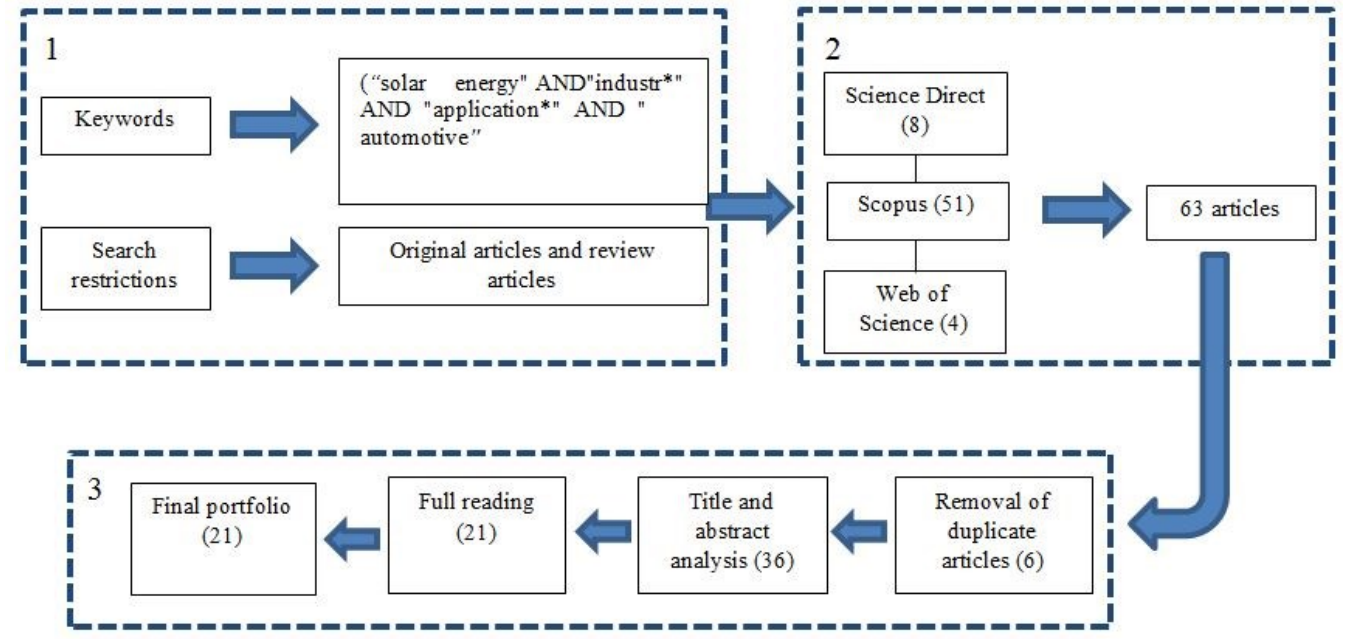

Source: Own Authorship (2020).

The investigation used the Science Direct, Scopus and Web of Science databases for review and research articles, with no time frame. It is justified that the selection of the Science Direct, Scopus and Web of Science databases occurred because they are bases widely used in literature review research, contributing to a scientific view of renewable energy in the industrial sector and the use of third generation materials in energy production (MÜLLER et al., 2017; SAHAYM; Norton, 2008). Science Direct, Scopus and Web of Science have shown high impact coverage in journals, however, according to the results reported by Famiglietti et al., (2020), both bases provide extensive bibliographic coverage in the area of Exact Sciences. The choice without the time frame is justified to identify how this field has behaved over the years, in order to identify the gap in this type of study.

For the definition of the keyword group, Boolean operators and truncation symbols were used, as follows: ("solar energy" AND "industr*" AND "application*"). After searching the databases, as shown in Figure 1, 63 articles were obtained. As a result, the 6 duplicate articles were excluded, resulting in 57 . Filtering by title and abstract was performed, eliminating articles that did not fit this investigation, excluding 36 articles in total and leaving 21 articles.

Subsequently, the InOrdinatio formula was adopted, where all articles were selected. Thus, a complete analysis was performed on the 21 articles. For this procedure, equation 1 was used:

InOrdinatio $=(\mathrm{Fi} / 1000)+\mathrm{a}^{*}[10-($ AnoPesq - AnoPub $)]+(\Sigma \mathrm{Ci})$

Where:

If: Impact factor

a: Coefficient attributed by the researcher;

APe: yearofresearch;

APu: Year of publication of thearticle;

$\mathrm{Ci}$ : Citation number of the article in other studies.

The software Mendeley, Microsoft Excel and Jabref were used. Bibliometric analysis was performed through the number of citations in the article defined by Google Scholar, impact factor where JCR 2018 (Journal Citation Reports) was considered, these data were collected on May 10, 2020. In the InOrdinatio coefficient is considered the year of publication with a score (a) that is ranked from 1 to 10 , according to the 
author's choice, the closer to 10 it means that the author considers the importance of updated articles in relation to the year of publication. The selection of authors was 5 , since no time frame was defined.

The 21 high-impact articles are shown in the results and discussion section. Visual maps were built using the VOSviewer software. For a complete assessment of the choice of articles, in addition to the criteria already mentioned, such as year of publication, impact factor and number of citations, other factors were analyzed such as: theme of the article, main topics (renewable energy, photovoltaic energy, applications and industry) and the country of research.

\section{RESULTS ANDDISCUSSION}

The classifications of high impact articles according to the InOrdinatio coefficient are presented in Table 1.

Table 1 - Final Result of Systematic Review

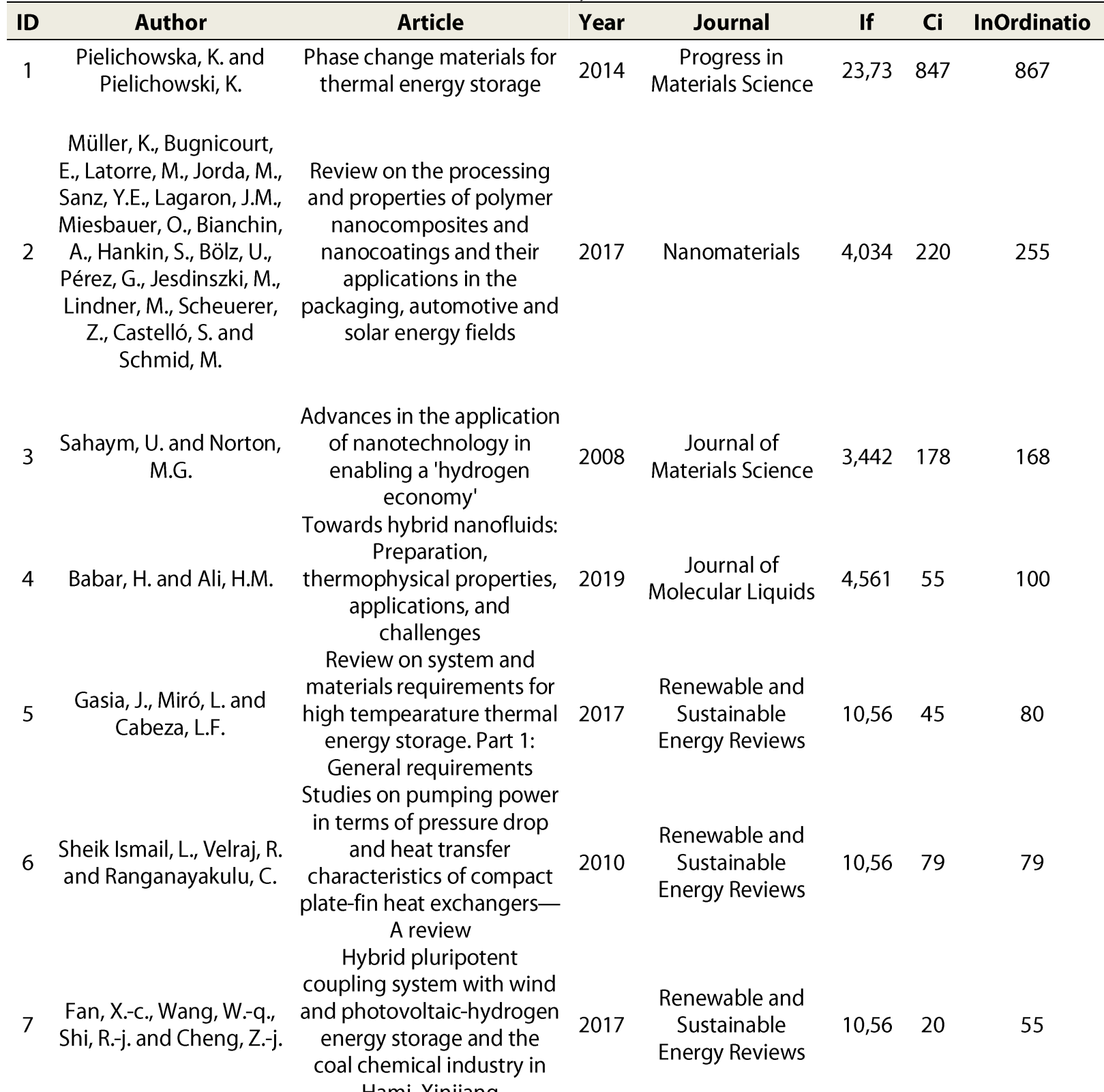
Hami, Xinjiang 
Dispenza, G., Sergi, F., Napoli, G., Randazzo, N.,

8 Di Novo, S., Micari, S., Antonucci, V. and Andaloro, L.

Sukumaran, $\mathrm{C}$ Vivekananthan, $V_{\text {., }}$

9 Mohan, V., Alex, Z.C.

Chandrasekhar, A. and Kim, S.J.

Famiglietti, A., Lecuona-

10 Neumann, A., Nogueira J. and Rahjoo, $M$.

Sheikh, N.A., Ali, F., Khan, I. and Gohar, M.

Bucher, T., Cardenas, S. Lawrence Yao, Y.

12 Jradi, M. and Riffat, S.
Development of a solar

powered hydrogen fueling station in smart cities applications

2017

Triboelectric

nanogenerators from reused plastic: An approach for vehicle security

2020 alarming and tire motion monitoring in rover

Direct solar production of medium temperature hot air for industrial applications in linear concentrating solar collectors using an open Brayton cycle. Viability analysis

Laser forming of sandwich panels with metal foam cores

Modelling and testing of a hybrid solar-biomass ORCbased micro-CHP system

A theoretical study on the performance of a solar collector using $\mathrm{CeO} 2$ and $\mathrm{Al} 2 \mathrm{O} 3$ water based nanofluids with inclined plate: Atangana-Baleanu fractional model

Dispenza, G., Sergi, F., Evaluation of hydrogen

14 Napoli, G., Antonucci, V. production cost in different and Andaloro, L.

Yeniyil, E., Boga, C. and Esme, $U$.

16 Kasti, N.A

Effects of ultrasonic welding parameters for solar collector applications Ranges of applicability of a solar-battery car with single and double solar-trailers

Patrusheva, T.N., The application of titanium

Fedyaev, V.A., Kirik, S.D. Rudenko, R.Y. and Khol'kin, A.I. dioxide coatings by the extraction-pyrolysis method

Mansoor, B., Nassar, H.,

18 Shunmugasamy, V.C. and Khraisheish, M.K.

Three dimensional forming of compressed open-cell metallic foams at elevated temperatures
2019

Journal of Laser Applications

International

2014 Journal of Energy

$3,343 \quad 28$

Research

Chaos, Solitons and Fractals

$3,064 \quad 6$

46

2019

Journal of Energy Storage

$3,517 \quad 0$

45

2019

Material pruefung/ Materials Testing

Solar Energy

$4,674 \quad 5$

Theoretical

Foundations of Chemical

$0,52 \quad 1$ 36

Engineering

2015

Materials Science and Engineering $A$
Journal of $\quad 4,084 \quad 20 \quad 55$ 


\section{Karaca, G. and} Tasdemir, Y.
Removal of polycyclic aromatic hydrocarbons (PAHs) from industrial sludges in the ambient air conditions: Automotive Industry
A., Ueno, T., Maeda, T. and Tokuoka, T.

21
Ishimine, T., Watanabe,

$$
\text { Finley, J.J. }
$$

Development of low-ironloss powder magnetic core material for high-frequency applications

Heat treatment and bending of low-E glass

\author{
Journal of \\ Environmental \\ Science and \\ $2013 \begin{aligned} & \text { Health - Part A } \\ & \text { Toxic/Hazardous }\end{aligned}$ \\ Substances and \\ Environmental \\ Engineering
}

$1,536 \quad 15$

30

2011

SEI Technical
Review

$1,618 \quad 12$

17

1999 Thin Solid Films

$1,888 \quad 58$

3

\section{Source: Own Authorship (2020).}

The results are presented according to the final portfolio of 21 articles, after having passed the criteria in the selection process described in the methodology. The theme is recent and constantly developing. Using text data, a map was constructed considering titles and abstracts, full counting method with a minimum number of occurrences of 5 , so 29 terms out of a total of 1008 met the criteria, with a total of 266 links, as shown in Figure 2.

Figure 2 - Co-occurrence of terms - final portfolio

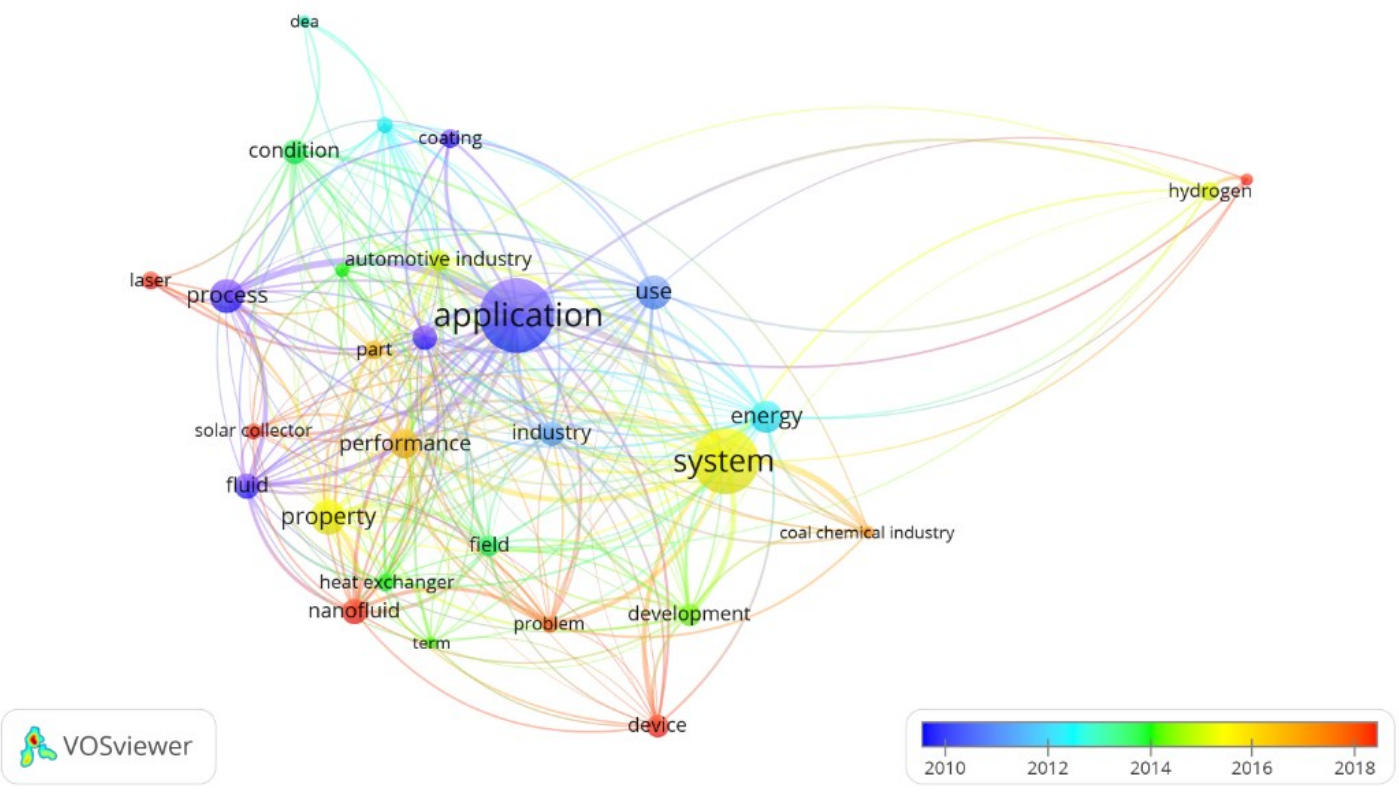

Source: Own Authorship (2020)

In the co-occurrence of terms and their interrelations, various topics have been addressed within the theme of Energy applications in the industry from photovoltaic. As Figure 2 shows the terms in the median of the years of their appearance, it is possible to conclude that terms in blue (progress, fluid, coaching, application, use, energy) are subject of the first high impact studies, according to the filters applied in this study. The terms in green and shades of yellow comprise more recent approaches, once they appear only in the last few years. Therefore, it can be seen that high impact research has been being conducted on the field, term, development, heat exchanger, dea, condition e automotive (green) since 2013 and 2014 (MÜLLER et al., 2017); in addiction, between 2015 and 2016, research on the hydrogen system, property and industry (yellow). 
In 2017, the following terms were highlighted: performance and coal chemical industry (orange). The terms laser, solar collection, nanofluid, device e problem (red) in 2018 these surveys, besides the theme Direct solar production of medium temperature for industrial applications (FAMIGLIETTI et al., 2020); Impacts of ultrasonic industrial welding for applications in solar collectors (YENIYIL; BOGA; ESME, 2019); Theoretical research of the performance of a solar collector using fluids (Sheikh et al., 2018); Use of solar batteries in vehicles (KASTI, 2017); Analysis of the properties of polymer nanocomposites and their automotive and solar photovoltaic applications (MÜLLER et al., 2017); Wind and photovoltaic-hydrogen storage system in the industry (FAN et al., 2017); Development of a hydrogen station powered by solar energy in various applications (DISPENZA et al., 2017); Model Study of a hybrid solar biomass micro based on Rankine cycle, combined system of energy and heat (JRADI; RIFFAT, 2014); Study on renewable energy possibilities for industry (KARACA;TASDEMIR, 2013). A co-authoring map was prepared based on bibliographic data, as presented in Figure 3.

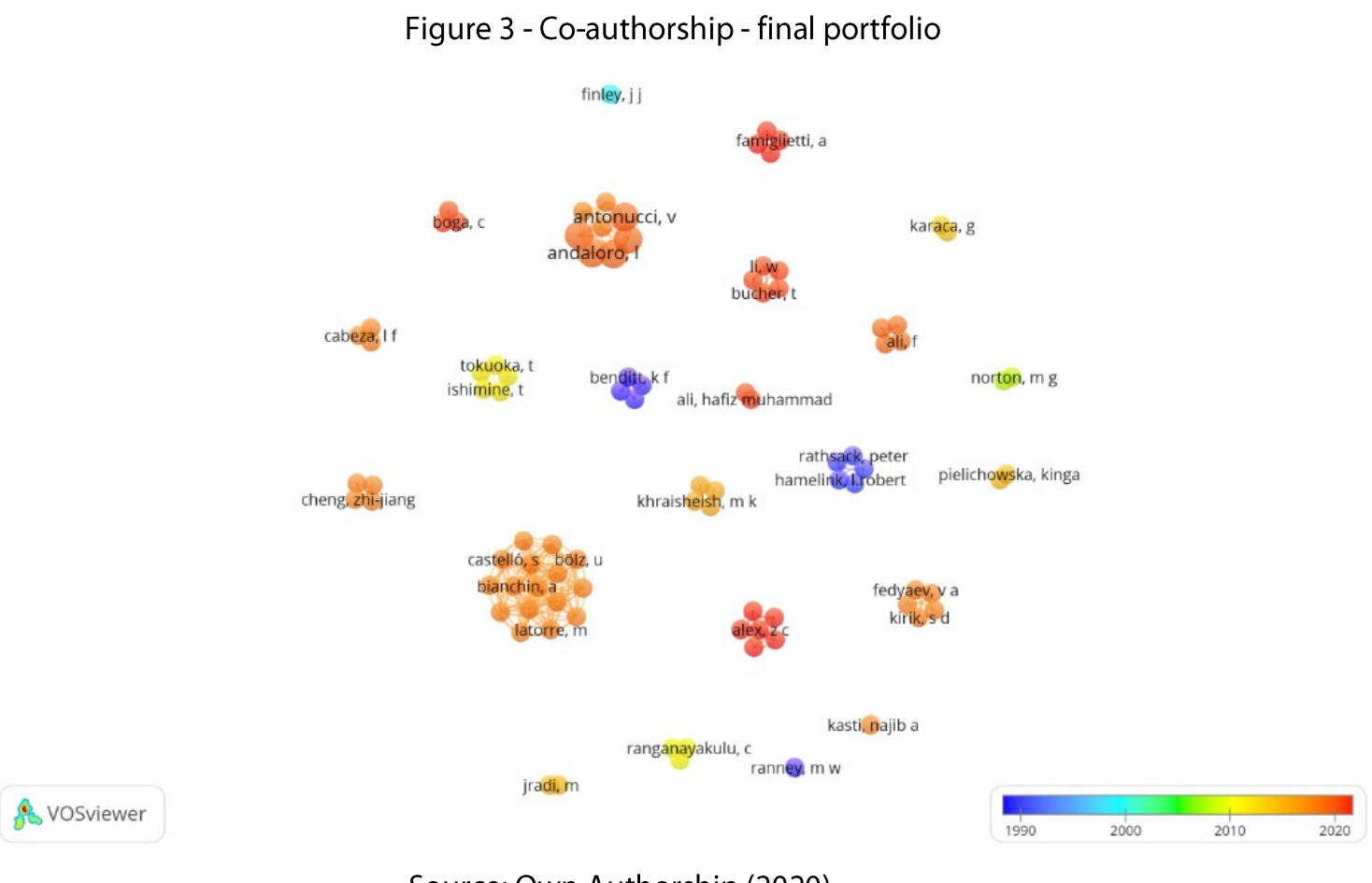

Source: Own Authorship (2020).

The co-authorship map, though, was based on bibliographic data, co-authorship as type of analysis and authors as unit of analysis, full counting as counting method and the clusters according to the number of documents per author. The network found was 92 authors and coauthors, with the formation of 23 clusters (authors who conducted joint studies), totaling 247 ties. The classification of publications by country is shown in Figure 4. 
Figure 4 - Number of publications per country

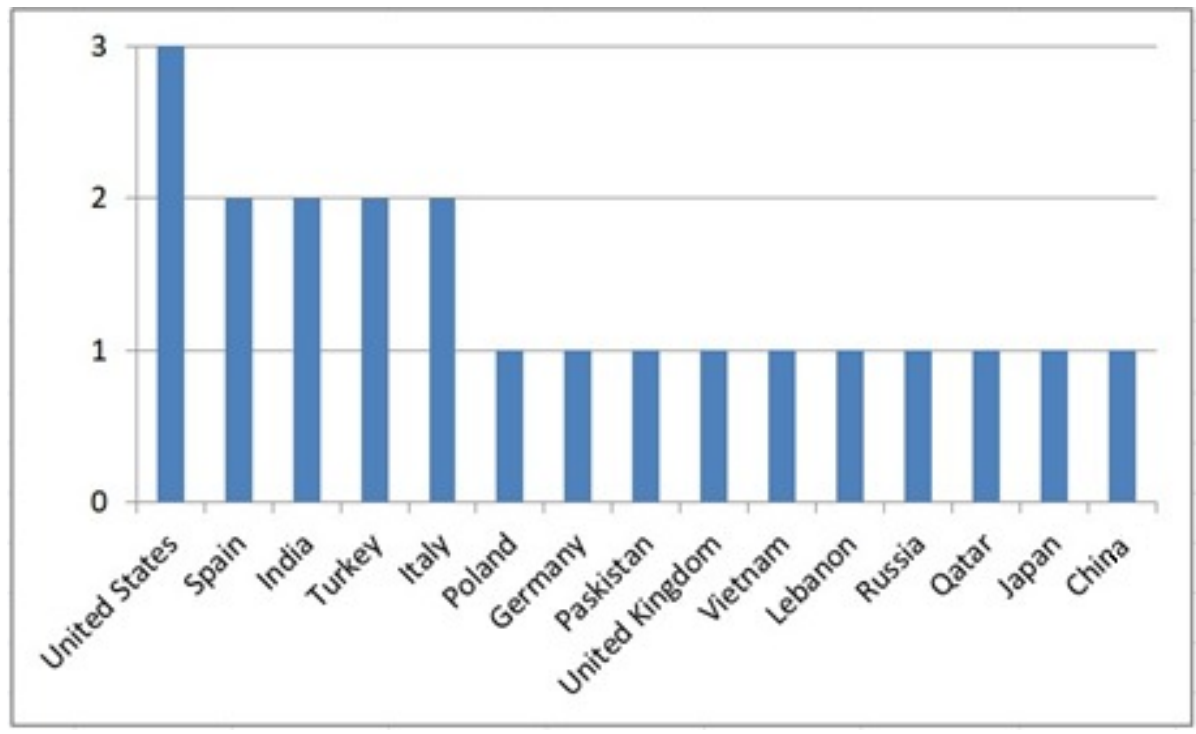

Source: Own Authorship (2020).

Poland, Germany, United States and Pakistan are the countries with the highest impact articles on the topic (with InOrdinatio> 100). Developed countries seem to be more concerned with the issue. Countries like India and Turkey, however, are prominent in representing the group of developing countries with high impact publications. Sheik Ismail, Velraj, Ranganayakulu (2010) in India research heat exchangers to transfer energy from one fluid to another in applications in the industry.

Sukumaran et al., (2020) present applications of green energy sources for devices in industries. Yeniyil, Boga and Esme, (2019) describe in their study in Turkey impacts of technologies and applications on solar collectors in industries. And Karaca and Tasdemir, (2013) an increase in automotive industrial energy efficiency.

Regarding the number of publications per year, Figure 5 shows from the first article on, according to the classification determined by the method of this study.

Figure 5 - Number of publications per year

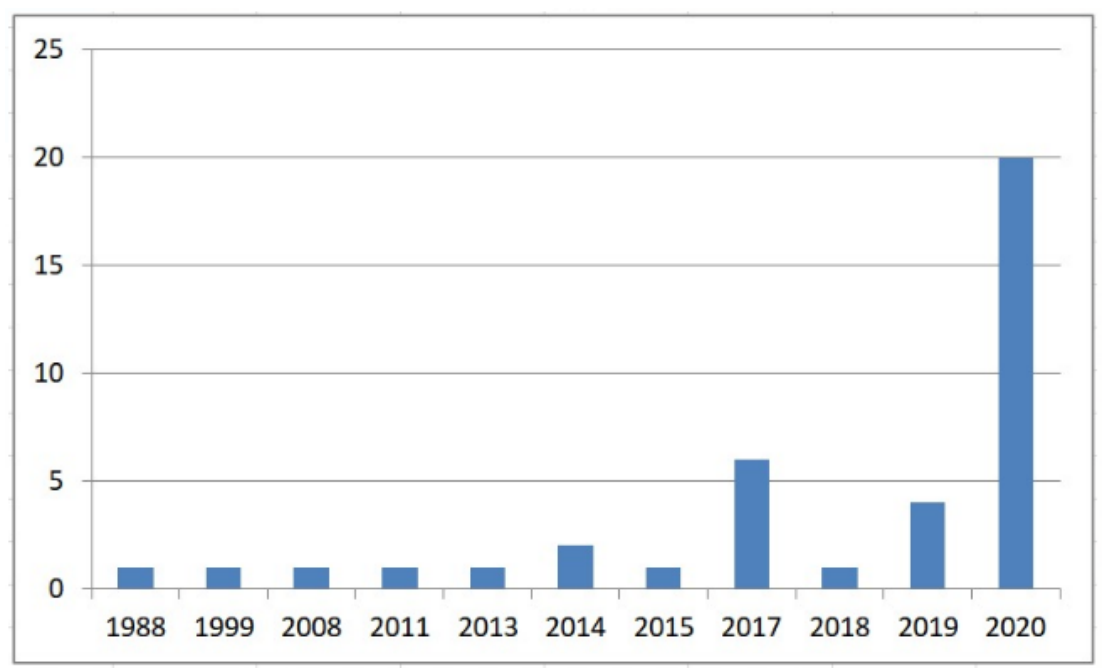

Source: Own Authorship (2020).

There was a big increase in the number of publications on the topic in 2017 and a reduction in 2018 and an increase in the number of articles in 2020, however, it is still too early to reach conclusions on trends, since there is still no extensive history. The theme seems to be in an early stage of development, being a 
favorable area for the improvement of high impact research in the coming years. Analyzing the 21 articles, sixteen performed a literature review and five did an experimental research, as shown in Table 2.

Table 2 - Solar Energy Applications in Industry

\begin{tabular}{|c|c|c|c|}
\hline Solar Energy Applications in Industry & Authors & Country & Methodology \\
\hline $\begin{array}{l}\text { Analyzes the current state of the art for } \\
\text { energy storage applications and } \\
\text { provides insight into recent } \\
\text { efforts with better performance and } \\
\text { safety. }\end{array}$ & $\begin{array}{l}\text { Pielichowska; Pielichowski, } \\
\text { (2014) }\end{array}$ & Poland & $\begin{array}{l}\text { Literature } \\
\text { review }\end{array}$ \\
\hline $\begin{array}{l}\text { Studies the processing and properties } \\
\text { of polymers and their applications in } \\
\text { the fields of packaging, solar energy } \\
\text { and automotive. }\end{array}$ & $\begin{array}{l}\text { Müller; Bugnicourt; Latorre; } \\
\text { Jorda; Sanz; Lagaron; } \\
\text { Miesbauer; Bianchin; Hankin; } \\
\text { Bölz; Pérez; Jesdinszki; Lindner; } \\
\text { Scheuerer; Castelló; Schmid, } \\
\text { (2017) }\end{array}$ & Germany & $\begin{array}{l}\text { Literature } \\
\text { review }\end{array}$ \\
\hline $\begin{array}{l}\text { Study on advances in the use of } \\
\text { nanomaterials for solar hydrogen } \\
\text { production and storage on board solid- } \\
\text { state hydrogen. }\end{array}$ & Sahaym; Norton, (2008) & $\begin{array}{l}\text { United } \\
\text { States }\end{array}$ & $\begin{array}{l}\text { Experimental } \\
\text { research }\end{array}$ \\
\hline $\begin{array}{l}\text { Analysis of application of hybrid } \\
\text { nanofluids in different areas, such as } \\
\text { solar energy, heat pipes, heat } \\
\text { exchangers, cooling of electronic } \\
\text { equipment. }\end{array}$ & Babar; Ali, (2019) & Paskistan & $\begin{array}{l}\text { Literature } \\
\text { review }\end{array}$ \\
\hline $\begin{array}{l}\text { Study on high temperature thermal } \\
\text { energy storage as an enormous energy } \\
\text { saving potential in industrial } \\
\text { applications, such as heating, solar } \\
\text { energy, refrigeration and heat recovery } \\
\text { from industrial waste. }\end{array}$ & Gasia; Miró; Cabeza, (2017) & Spain & $\begin{array}{l}\text { Literature } \\
\text { review }\end{array}$ \\
\hline $\begin{array}{l}\text { Analysis of heat exchanger as a device } \\
\text { to transfer energy from one fluid to } \\
\text { another for many applications in } \\
\text { buildings, industries and automobiles. }\end{array}$ & $\begin{array}{c}\text { Sheik Ismail; Velraj; } \\
\text { Ranganayakulu, (2010) }\end{array}$ & India & $\begin{array}{l}\text { Literature } \\
\text { review }\end{array}$ \\
\hline $\begin{array}{l}\text { Applications of hybrid multi-energy } \\
\text { coupling system, which includes } \\
\text { complementary photovoltaic system, } \\
\text { energy storage and distribution system } \\
\text { for industry. }\end{array}$ & Fan; Wang; Shi; Cheng, (2017) & China & $\begin{array}{l}\text { Literature } \\
\text { review }\end{array}$ \\
\hline $\begin{array}{c}\text { Study on the Development of a Solar } \\
\text { Powered Hydrogen Station in } \\
\text { Intelligent Applications }\end{array}$ & $\begin{array}{c}\text { Dispenza; Sergi; Napoli; } \\
\text { Randazzo; Di Novo; Micari; } \\
\text { Antonucci; Andaloro, (2017) }\end{array}$ & Italy & $\begin{array}{l}\text { Experimental } \\
\text { research }\end{array}$ \\
\hline $\begin{array}{l}\text { Sustainable energy source as a } \\
\text { potential device in the future of } \\
\text { robotics, industries and tire movement } \\
\text { monitoring in mobile applications. }\end{array}$ & $\begin{array}{l}\text { Sukumaran; Vivekananthan; } \\
\text { Mohan; Alex; Chandrasekhar; } \\
\text { Kim, (2020) }\end{array}$ & India & $\begin{array}{l}\text { Literature } \\
\text { review }\end{array}$ \\
\hline $\begin{array}{c}\text { Direct solar production of medium } \\
\text { temperature hot air for industrial } \\
\text { applications in linear concentrating } \\
\text { solar collectors using an open Brayton } \\
\text { cycle. }\end{array}$ & $\begin{array}{l}\text { Famiglietti; Lecuona-Neumann; } \\
\text { Nogueira; Rahjoo, (2020) }\end{array}$ & Spain & $\begin{array}{l}\text { Literature } \\
\text { review }\end{array}$ \\
\hline
\end{tabular}




\begin{tabular}{|c|c|c|c|}
\hline $\begin{array}{c}\text { Economic and technical feasibility of } \\
\text { renewable energies for deployment in } \\
\text { industries. }\end{array}$ & $\begin{array}{l}\text { Bucher; Cardenas; Verma; Li; } \\
\text { Lawrence Yao, (2019) }\end{array}$ & $\begin{array}{l}\text { United } \\
\text { States }\end{array}$ & $\begin{array}{l}\text { Literature } \\
\text { review }\end{array}$ \\
\hline $\begin{array}{c}\text { Applications and Modeling with testing } \\
\text { of a hybrid solar biomass. }\end{array}$ & Jradi; Riffat, (2014) & $\begin{array}{l}\text { United } \\
\text { Kingdom }\end{array}$ & $\begin{array}{l}\text { Experimental } \\
\text { research }\end{array}$ \\
\hline $\begin{array}{c}\text { Analysis of nanofluid as a decisive role } \\
\text { in different thermal applications, such } \\
\text { as heat exchangers and solar energy } \\
\text { generation. }\end{array}$ & Sheikh; Ali; Khan; Gohar, (2018) & Vietnam & $\begin{array}{l}\text { Literature } \\
\text { review }\end{array}$ \\
\hline $\begin{array}{l}\text { Hydrogen production cost study at a } \\
\text { solar power plant with relevant } \\
\text { economic and environmental benefits } \\
\text { operation of the installation. }\end{array}$ & $\begin{array}{c}\text { Dispenza; Sergi; Napoli; } \\
\text { Antonucci; Andaloro, (2019) }\end{array}$ & Italy & $\begin{array}{l}\text { Experimental } \\
\text { research }\end{array}$ \\
\hline $\begin{array}{l}\text { Impacts of the effects on ultrasonic } \\
\text { welding for technologies and } \\
\text { applications in solar collectors in the } \\
\text { industry. }\end{array}$ & Yeniyil; Boga; Esme, (2019) & Turkey & $\begin{array}{l}\text { Literature } \\
\text { review }\end{array}$ \\
\hline $\begin{array}{c}\text { Technical possibilities for the } \\
\text { deployment of renewable energies in } \\
\text { cities and industries. }\end{array}$ & Kasti, (2017) & Lebanon & $\begin{array}{l}\text { Literature } \\
\text { review }\end{array}$ \\
\hline $\begin{array}{l}\text { The photovoltaic coating is suitable for } \\
\text { industrial and construction } \\
\text { applications. }\end{array}$ & $\begin{array}{l}\text { Patrusheva; Fedyaev; Kirik; } \\
\text { Rudenko; Khol'kin, (2017) }\end{array}$ & Russia & $\begin{array}{l}\text { Experimental } \\
\text { research }\end{array}$ \\
\hline $\begin{array}{l}\text { Study on Development of effective } \\
\text { downstream processes with complex } \\
\text { geometries in various sustainable } \\
\text { applications, such as fuel cells, } \\
\text { advanced heat exchangers and } \\
\text { concentrated solar power plants. }\end{array}$ & $\begin{array}{c}\text { Mansoor; Nassar; } \\
\text { Shunmugasamy; Khraisheish, } \\
\text { (2013) }\end{array}$ & Qatar & $\begin{array}{l}\text { Literature } \\
\text { review }\end{array}$ \\
\hline $\begin{array}{c}\text { Improvement in energy efficiency in the } \\
\text { automotive industry. }\end{array}$ & Karaca; Tasdemir, (2013) & Turkey & $\begin{array}{l}\text { Literature } \\
\text { review }\end{array}$ \\
\hline $\begin{array}{c}\text { The energy study for the development } \\
\text { of clean energy generation systems, } \\
\text { such as solar and wind generators. }\end{array}$ & $\begin{array}{l}\text { Ishimine; Watanabe; Ueno; } \\
\text { Maeda; Tokuoka, (2011) }\end{array}$ & Japan & $\begin{array}{l}\text { Literature } \\
\text { review }\end{array}$ \\
\hline $\begin{array}{l}\text { Research on the use of low-E coatings, } \\
\text { reflecting solar energy, is a more } \\
\text { efficient way to reduce the } \\
\text { accumulation of solar heat. }\end{array}$ & Finley, (1999) & USA & $\begin{array}{l}\text { Literature } \\
\text { review }\end{array}$ \\
\hline
\end{tabular}

Source: Own Authorship (2020).

There are authors who claim applications of renewable energies in the industrial sector. Studies show feasibility analysis on solar production for industrial applications (FAMIGLIETTI et al., 2020); performance of a water-based solar collector (SHEIKH et al., 2018); Process for storing wind and photovoltaic-hydrogen in Chinese industry (FAN et al., 2017); energy efficiency in the automotive industry (KARACA; TASDEMIR, 2013)

Some authors claim that photovoltaic systems are great investment opportunities with rates of return like investments with high profitability. The difficulty in energy generation and distribution systems are longterm investments with payback ranging from 8 to 15 years depending on the size of the project. Investments in this type of project show low liquidity depending on technical factors such as maintenance, equipment, installation and qualified and trained professionals (FAMIGLIETTI et al., 2020; YENIYIL;BOGA;ESME, 2019; KASTI, 2017).

Other research, however, shows little incentive from the government system to encourage and promote the adoption of new sustainable technologies for the process of generation and distribution of renewable energy in order to decrease industrial costs in financing with favorable energy rates (SUKUMARAN et al. 2020; BUCHER et al. 2019; YENIYIL; BOGA; ESME, 2019; KASTI, 2017; MÜLLER et al., 2017). 
Several countries in the world show a high potential to maintain the energy matrix based on clean energy sources. The development of photovoltaic technologies, reducing costs in installation and storage systems, requires a partnership between research institutions, private companies and political systems (FAMIGLIETTI et al., 2020; DISPENZA et al., 2019; SHEIKH et al., 2018; ISHIMINE et al., 2011; FINLEY, 1999). Also see Table 3 (Industry Applications).

Table 3 - Industry Applications

\begin{tabular}{|c|c|}
\hline Photovoltaic applications in industry & Authors \\
\hline Water heating for restaurants and bathrooms & Karaca and Tasdemir, 2013. \\
\hline Administrative and production air heaters & Müller et al., 2017; Jradi and Riffat, 2014. \\
\hline Energy in the generation of electricity in equipment & Sheikh et al., 2018; Fan et al. 2017. \\
\hline Vehicle fuel in the internal fleet & $\begin{array}{c}\text { Famiglietti et al., 2020; Yeniyil, Boga and } \\
\text { Esme, 2019; Kasti, 2017. }\end{array}$ \\
\hline Substitution to natural gas & Dispenza et al. 2019; Dispenza et al. 2017. \\
\hline
\end{tabular}

Source: Own Authorship (2020).

The industrial applications for photovoltaic solar energy found in the systematic literature review were water heating for industrial restaurants, heaters and bathrooms, as well as energy in the generation of electricity in industrial plant equipment, as vehicle fuel in the internal industrial fleet and substitution natural gas. The use of clean energy sources favors the industrial sector, resulting in increased production, reduced costs and acting in a sustainable and competitive way (FAMIGLIETTI et al., 2020; DISPENZA et al., 2019; YENIYIL; BOGA; ESME, 2019; SHEIKH et al., 2018; DISPENZA et al., 2017; FAN et al., 2017; KASTI, 2017; MÜLLER et al., 2017; JRADI; RIFFAT, 2014; KARACA;TASDEMIR, 2013).

From the analyzed articles, the following results were obtained: $19.7 \%$ found technical benefits for the use of clean sources of photovoltaic energy in industry; $12.8 \%$ affirm that human and economic development requires the availability of energy resources for the production of renewable electric energy, close to the final customer and minimizing losses in distribution lines; and 67.5\% show that the diversification of the industrial energy matrix demonstrates several economic, environmental and social advantages, therefore, reducing the dependence on fossil resources.

Diversification of the industrial energy matrix with the use of solar energy contributes to energy security with reliability in the supply of energy, safety of the environment with restriction of environmental impacts and economic security with electricity generation at a competitive cost.

The articles also mentioned the social advantages of using solar energy as a source of clean energy to build a more sustainable future for humanity. The use of solar energy has become as the great solution for all the energy problems of our society. The use of solar energy presents an important alternative to contain uncertainties in a more sustainable local way and preventively in locations in situations of social vulnerability.

\section{FINAL CONSIDERATIONS}

The aim of this study was to analyze the environmental, economic and social impacts and applications of photovoltaic solar energy in the industrial sector. The objective was achieved by explaining the main studies that describe the elements that influence the development of solar photovoltaic energy.

A mapping of 21 studies that analyzed the use and benefits of this clean energy source was carried out. The results of this research show that the development of clean energy sources in the countries' energy matrix is essential, due to the growth with impacts on the environment such as the emission of greenhouse gases, climate changes and global warming of the planet, and energy demands. Therefore, photovoltaic energy is a relevant opportunity for generating energy with inexhaustible characteristics and the possibility of generating energy close to the end customer, producing no noise in its generation, requiring additional areas for the installation of panels and enabling insertion in the industry. 
In the industrial sector of some countries, such as the United States, Spain, India, Turkey and Italy, the photovoltaic solar energy market has grown in recent years, encouraging the emergence of government tax reduction programs, thus, increasing the number of investors and decreasing the component values driving the expansion in the industry.

The potential is promising in advancing technologies to harness solar energy, photovoltaic generation and distribution systems are generally independent, with installations in remote locations. The systems connected to the electricity grid show a low installed power originating from research and development projects with educational institutions.

Among the benefits for the industrial sector with the use of solar energy are: the reduction of impacts on the environment, energy and economic savings, photovoltaic solar panels with durability and little maintenance, installation of the system is practical and simple, tax incentives, green marketing and competitive advantage. Therefore, it is possible to reduce the environmental and economic impact, thanks to the installation of a photovoltaic system in the industrial sector. Other strategies have been adopted to mitigate the economic optimum environmental impact: reducing the energy tariffs and the costs of technologies.

The reduction of tariffs with solar energy, however, without a significant reduction in technology costs, is not very effective for the environment. Indeed, a cost reduction in equipment for the generation of solar energy allows the economic optimum environmental impact in industrial sector to get much closer to the minimum also having an economic advantage.

In the social area, solar energy needs to be disseminated to assist in initiatives for the distribution of wealth and sustainability, especially in areas with a population that can be characterized in a situation of socioeconomic vulnerability.

Regarding the limitations of the review, the study includes only publications of journals from the Scopus, Science Direct and Web of Science databases. The article analyzed only the applications and impacts of photovoltaic solar energy in the industrial sector, and analysis in other sectors is suggested. One difficulty found in the present study was to evaluate the losses in the generation of solar photovoltaic energy caused by the shading periods.

For future studies we suggest the analysis of technical and economic feasibility for the dimensioning of the photovoltaic solar system in the grid for localities and consumption of electricity through the free energy of the sun; the development of solid long-term partnerships between universities, government systems and industries, for generating a greater annual production of photovoltaic solar energy, and generation and distribution systems with attractive investments for installation.

\section{ACKNOWLEDGMENTS}

The present study was developed under the financial support of the Scholarship Program of Fundação Araucária and Renault Brazil and the Coordination of Improvement of Higher Education Personnel (CAPES).

\section{REFERENCES}

BABAR, H.; ALI, H. M. Towards hybrid nanofluids: Preparation, thermophysical properties, applications, and challenges. Journal of Molecular Liquids, v. 281, p. 598-633, 2019.

BUCHER, T., CARDENAS, S., VERMA, R., LI, W.; LAWRENCE YAO, Y. Laser forming of sandwich panels with metal foam cores. Journal of Laser Applications, v. 31, n. 2, 2019.

DISPENZA, G., SERGI, F., NAPOLI, G., RANDAZZO, N., DI NOVO, S., MICARI, S., ANTONUCCI, V.; ANDALORO, L.Development of a solar powered hydrogen fueling station in smart cities applications. International Journal of Hydrogen Energy, v. 42, n. 46, p. 27884-27893, 2017. 
DISPENZA, G., SERGI, F., NAPOLI, G., ANTONUCCI, V.; ANDALORO, L. Evaluation of hydrogen production cost in different real case studies. Journal of Energy Storage, v. 24, 2019.

FAMIGLIETTI, A., LECUONA-NEUMANN, A., NOGUEIRA, J.; RAHJOO, M. Direct solar production of medium temperature hot air for industrial applications in linear concentrating solar collectors using an open Brayton cycle. Viability analysis. Applied Thermal Engineering, v. 169, 2020.

FAN, X. C., WANG, W. Q., SHI, R. J.; CHENG, Z. J. Hybrid pluripotent coupling system with wind and photovoltaichydrogen energy storage and the coal chemical industry in Hami, Xinjiang. Renewable and Sustainable Energy Reviews, v. 72, p. 950-960, 2017.

FINLEY, J. J. Heat treatment and bending of low-E glass. Thin Solid Films, v. 351, n. 1, p. 264-273, 1999.

GASIA, J.; MIRÓ, L.; CABEZA, L. F. Review on system and materials requirements for high tempearature thermal energy storage. Part 1: General requirements. Renewable and Sustainable Energy Reviews, v. 75, p. 1320$1338,2017$.

ISENMANN, R.; BEY, C.; WELTER, M. Online reporting for sustainability issues. Business Strategy and the Environment, v. 16, p. 487-501, 2007

ISHIMINE, T., WATANABE, A., UENO, T., MAEDA, T.; TOKUOKA, T. Development of low-iron-loss powder magnetic core material for high-frequency applications. SEI Technical Review, n. 72, p. 117-123, 2011.

JRADI, M.; RIFFAT, S. Modelling and testing of a hybrid solar-biomass ORC-based micro-CHP system. International Journal of Energy Research, v. 38, n. 8, p. 1039-1052, 2014.

KARACA, G.; TASDEMIR, Y. Removal of polycyclic aromatic hydrocarbons (PAHs) from industrial sludges in the ambient air conditions: Automotive Industry. Journal of Environmental Science and Health - Part A Toxic/Hazardous Substances and Environmental Engineering, v. 48, n. 8, p. 855-861, 2013.

KASTI, N. A. Ranges of applicability of a solar-battery car with single and double solar-trailers. Solar Energy, v. 144, p. 619-628, 2017.

MANSOOR, B., NASSAR, H., SHUNMUGASAMY, V.C.; KHRAISHEISH, M.K. Three dimensional forming of compressed open-cell metallic foams at elevated temperatures. Materials Science and Engineering A, v. 628, p. 433-441, 2015.

MÜLLER, K., BUGNICOURT, E., LATORRE, M., JORDA, M., SANZ, Y.E., LAGARON, J.M., MIESBAUER, O., BIANCHIN, A., HANKIN, S., BÖLZ, U., PÉREZ, G., JESDINSZKI, M., LINDNER, M., SCHEUERER, Z., CASTELLÓ, S.; SCHMID, M. Review on the processing and properties of polymer nanocomposites and nanocoatings and their applications in the packaging, automotive and solar energy fields. Nanomaterials, v. 7, n. 4, 2017.

PAGANI, R. N.; KOVALESKI, J. L.; RESENDE, L. M. Methodi ordinatio: a proposed methodology to select and rank relevant scientific papers encompassing the impact factor, number of citation, and year of publication. Scientometrics, v. 105, n. 3, p. 2109-2135, 2015.

PATRUSHEVA, T.N., FEDYAEV, V.A., KIRIK, S.D., RUDENKO, R.Y.; KHOL'KIN, A.I. The application of titanium dioxide coatings by the extraction-pyrolysis method. Theoretical Foundations of Chemical Engineering, v. 51, n. 5, p. 759-762, 2017. 
PIELICHOWSKA, K.; PIELICHOWSKI, K. Phase change materials for thermal energy storage. Progress in Materials Science, v. 65, p. 67-123, 2014.

SAHAYM, U.; NORTON, M. G. Advances in the application of nanotechnology in enabling a "hydrogen economy". Journal of Materials Science, v. 43, n. 16, p. 5395-5429, 2008.

SHEIK ISMAIL, L.; VELRAJ, R.; RANGANAYAKULU, C. Studies on pumping power in terms of pressure drop and heat transfer characteristics of compact plate-fin heat exchangers-A review. Renewable and Sustainable Energy Reviews, v. 14, n. 1, p. 478-485, 2010.

SHEIKH, N.A., ALI, F., KHAN, I.; GOHAR, M. A theoretical study on the performance of a solar collector using CeO2 and $\mathrm{Al} 2 \mathrm{O} 3$ water based nanofluids with inclined plate: Atangana-Baleanu fractional model. Chaos, Solitons and Fractals, v. 115, p. 135-142, 2018.

SOUZA JUNIOR, A. J. et al. Energia solar em organizações militares: uma análise da viabilidade econômicofinanceira. Navus, Forianópolis, v.9, n.1, p. 63-73, jan./mar. 2019.

SUKUMARAN, C., VIVEKANANTHAN, V., MOHAN, V., ALEX, Z.C., Chandrasekhar, A.; Kim, S.-J. Triboelectric nanogenerators from reused plastic: An approach for vehicle security alarming and tire motion monitoring in rover. Applied Materials Today, v. 19, 2020.

YENIYIL, E.; BOGA, C.; ESME, U. Effects of ultrasonic welding parameters for solar collector applications. Materialpruefung/Materials Testing, v. 61, n. 4, p. 344-348, 2019. 